\title{
United Nations Volunteers: \\ Barriers and Opportunities for Youth Volunteerism in the Arab World ${ }^{1}$
}

\author{
Lesley Abraham \\ M.A. International Affairs | Online Volunteer $^{2}$ Researcher \\ Freelance Consultant | Ottawa \\ lesley.abraham@gmail.com
}

Waheeb Al-Eryani

M.Sc. Violence, Conflicts and Development | Programme Management Specialist $|U N V|$ Bonn

waheeb.aleryani@unv.org

The Arab region has experienced extraordinary political, social and economic upheaval in recent years, which has highlighted the poverty, unemployment and marginalization experienced by youth in the region. In response to these challenges, United Nations Volunteers (UNV) is supporting the programme "Arab Youth Volunteering for a Better Future". It aims to harness the energy of youth through volunteerism in order to enhance youth inclusion and participation in socioeconomic development. Using a participatory learning and action approach, the programme undertook a series of mapping and consultation exercises in five pilot countries (Egypt, Jordan, Morocco, Tunisia and Yemen) to gather information from youth and other stakeholders on perceptions, barriers and opportunities for volunteering. This paper explores the process and findings from these exercises, as well as

\footnotetext{
${ }^{1}$ The views expressed in this publication are those of the authors and do not necessarily represent those of the United Nations Volunteers. This consolidated summary would not have been possible without the work of various staff and personnel of the United Nations Volunteers programme. Special thanks to UN Volunteers and staff at the UNV field units who have been instrumental for this work.

${ }^{2}$ The UNV Online Volunteering service connects volunteers with organizations working for sustainable human development https://www.onlinevolunteering.org.
} 
how they will be incorporated into the next steps of the programme design. Barriers to volunteerism can be categorised into four categories: economic, cultural, social and infrastructural. Proposed solutions evolved around fostering a culture of volunteerism, developing supportive infrastructure for volunteerism, developing national capacities to support volunteerism and creating opportunities for inclusion.

Keywords: National Consultations, Youth Volunteering, Arab Youth Volunteering, Participatory Learning and Action Approach, Barriers to Volunteering, United Nations Volunteers, Volunteering Perceptions in the Arab World

\section{Introduction}

Over the past three years, the Arab world has experienced a series of popular uprisings demanding change. Spearheaded primarily by youth, these protests have drawn attention to the power of peaceful engagement for change. In several countries, these movements have changed attitudes towards youth and state governance, providing opportunities and creating expectations for greater participation of all. It has also highlighted the poverty, unemployment and marginalization experienced by Arab youth under the age of 25, who make up approximately 60 percent of the population (UNDP 2009).

In response to the challenges facing youth in the region, the Arab Youth Volunteering for a Better Future regional programme was initiated in 2011. This initiative aims to harness the power and energy of youth through volunteerism, and to build their strength and capacity in order to enhance youth social inclusion and participation in the socio-economic development of their countries. In particular, the programme aims to foster dialogue to facilitate youth-led engagement in development, to establish policy and institutional mechanisms to engage youth in volunteering for peace and development activities, and to promote volunteerism by creating youth platforms to exchange knowledge, best practices and experiences at the regional level. The initiative is being piloted in five countries: Egypt, Jordan, Morocco, Tunisia and Yemen.

The Arab Youth Volunteering for a Better Future programme is an initiative led by the United Nations Volunteers (UNV) programme and is in line with 
regional strategies of the United Nations (UN) and United Nations Development Programme (UNDP). The UNV programme is the UN organization that contributes to peace and development through volunteerism worldwide. UNV does so by advocating for recognition of volunteers, working with partners to integrate volunteerism into development programming, and mobilizing an increasing number and diversity of volunteers, including experienced UN Volunteers, throughout the world. UNV embraces volunteerism as universal and inclusive, and recognizes volunteerism in its diversity as well as the values that sustain it: free will, commitment, engagement and solidarity.

\section{Youth Volunteering in the Arab Region}

As in many regions throughout the world, there is a rich history of volunteerism and community support in the Arab world, though it has not always been formally labelled as such. In Arabic, volunteerism translates to (tatawa'a) (تطوع) which translates to "donating something" or to "commit to a charitable activity that is not a religious requirement"; the word originates from (al-taw'a) (الطوع), another Arabic word which means "compliance, smoothness and flexibility." While there are some perceptions that volunteerism is a Western concept, in many ways "volunteerism" and "civil society" are just new names for age-old traditions in the regions." (UNV 2011)

Much of the literature in volunteering in the region focuses on the long history of charity and philanthropic giving based on religious teachings (Ibrahim 2005, Underwood and Jabre 2010, Salih 2004). The focus has been primarily on the role of Islam, namely the concepts of zakat (one of the five pillars of Islam which outlines the giving of a portion of one's wealth to charity), waqf (a religious endowment in Islamic law), and sadaqa (a form of discretionary giving). However, the research also touches on the teachings of Christianity and Judaism as related to charity and volunteerism, though it seems this is less common given the demographic composition of the region.

Examinations of how policies, programmes and non-formal voluntary action can contribute to increased youth civic engagement have also been undertaken (Talcott 2011, La Cava 2010, UNESCO 2011). There has been a particular interest in this topic in the wake of the Arab Spring movements of 2010 and 2011. The role of youth in the uprisings, including the underlying 
political, social, economic and religious reasons driving their involvement, as well as their changing role in society has been widely explored (AlMomani 2011, Halaseh 2012, Hoffman and Jamal 2012, Issam Fares Institutes 2011).

However, there seems to be little research on formalized service volunteering in the region. At the regional level, there are some explorations of influences on the development of voluntary action in the region (Kandil 2004) as well as case studies on volunteerism in the Arab world (Shtewi 2000). There is also some country-specific research on volunteering in Egypt (Ali 2012, Sedky 2011). A contributing factor to the paucity of literature in this area may be due in part to the lack of recognition and measurement of voluntary activity in the region, as it has been suggested that there is little data collection or regular monitoring on volunteer efforts (Arab Network for NGOs 2011). Another contributing factor may be the lack of civil society capacity and weak non-profit infrastructure which is found in the region (Kandil 2010, Rishmawi and Morris 2007), which makes it difficult for organizations to host volunteers.

There seem to be few national or regional service volunteering programs in operation, although there are a number of international service programs in each of the project countries via UNV as well as other organizations.

\section{Programme Development using a Participatory Learning Action Approach}

Since its inception in 2011, the Arab Youth Volunteering for a Better Future programme has utilized a youth-led participatory approach to programme design and implementation. As the first part of this process, national volunteers were recruited by UNV in each of the project countries to undertake mapping exercises on youth volunteerism. Between January and April 2012, these five volunteers, supported by UNV field units, and UNV HQs reviewed data from various reports, interviews, surveys and other documents and prepared comprehensive reports providing an overview of the relevant existing programs and research in their respective countries.

The mapping reports were then used to guide the development and implementation of national consultation workshops in each of the project countries. These two-day workshops were facilitated by UNV between April and 
October 2012 and included approximately 250 participants in total representing a cross-section of various backgrounds and sectors. The objectives of the workshops were to:

- Bring youth, civil society actors, government representatives and leading partners together, and facilitating constructive participatory dialogue around youth issues;

- Create an enabling environment for youth-led engagement in programme design and implementation;

- Define the main priorities of relevance to youth, and identifying potential activities as inputs for the programme document; and

- Identify main stakeholders for future implementation of planned activities.

A participatory learning and action (PLA) approach was used for the consultation workshops to ensure that youth were involved in the project conceptualization and design and to ensure shared ownership of decision-making processes (see Table 1). Accordingly, the workshop was divided into three main sections: (1) setting the scene, (2) issue identification and (3) project development. The first section focused on establishing positive group dynamics through a series of interactive exercises, setting personal objectives and expectations and introducing to the general objectives of the workshop. In the second section, participants were asked to discuss definitions of volunteering and the motivations for engaging in volunteer activities. Based on the outcomes of this discussion - that is, the barriers and issues identified participants were then invited to brainstorm initiatives to address these factors. The third section of the workshop consisted of break-outs into smaller groups which were divided according to thematic discussions at the institutional, organizational and individual level. Based on the barriers identified by the working groups, the same working groups lastly developed activities to overcome barriers, identify stakeholders and anticipate results for these activities. These activity suggestions were then compiled by the workshop facilitators. Research findings from both the mapping exercises and the consultation workshops are outlined in the following sections of this paper. 


\begin{tabular}{|c|c|}
\hline $\begin{array}{l}\text { Aspirational aims of } \\
\text { PLA good practice } \\
\text { (Bradley and Schneider } \\
\text { 2004, adapted from } \\
\text { Pretty 1994) }\end{array}$ & $\begin{array}{l}\text { Tools and methodologies used by consultation workshops } \\
\text { for the Arab Youth Volunteering for } \\
\text { a Better Future programme }\end{array}$ \\
\hline $\begin{array}{l}\text { Defined methodology } \\
\text { and system of learning } \\
\text { and interaction }\end{array}$ & $\begin{array}{l}\text { PLA methodologies were used based on existing } \\
\text { literature (Bradley and Schneider 2004, IIED } \\
\text { 2011) } \\
\text { Learning and interaction tools and methodologies } \\
\text { were used including a motivation wheel, focus } \\
\text { groups and problem trees }\end{array}$ \\
\hline $\begin{array}{l}\text { Emphasis on the } \\
\text { validity of partici- } \\
\text { pants' different opin- } \\
\text { ions and perspectives }\end{array}$ & $\begin{array}{l}\text { The workshop included space for the sharing of } \\
\text { individual stories and experiences, and used these } \\
\text { examples as real-life case studies for identifying } \\
\text { potential activities and areas for intervention for } \\
\text { the programme }\end{array}$ \\
\hline $\begin{array}{l}\text { Group learning proc- } \\
\text { esses, involving } \\
\text { interaction of devel- } \\
\text { opment workers with } \\
\text { local people, and } \\
\text { interaction of different } \\
\text { disciplines and sectors }\end{array}$ & $\begin{array}{l}\text { Participants included representatives from a wide } \\
\text { range of stakeholders including young people, the } \\
\text { private sector, national and international NGOs, } \\
\text { UN agencies, civil society, government officials } \\
\text { and academics. Care was also taken to ensure } \\
\text { there was a balance of different social back- } \\
\text { grounds, gender and age. The diversity of the par- } \\
\text { ticipants resulted in a broad range of opinions and } \\
\text { interests being represented at the consultation. } \\
\text { Both large group and small group discussions } \\
\text { were facilitated. } \\
\text { In order to achieve maximum input from all par- } \\
\text { ticipants, each thematic working group was invited } \\
\text { to provide input and feedback on the others' pro- } \\
\text { posed activities. In doing so, the thematic working } \\
\text { groups were able to prioritize their activities and } \\
\text { incorporate ideas and suggestions from their peers } \\
\text { and other stakeholders. }\end{array}$ \\
\hline $\begin{array}{l}\text { Flexible approaches } \\
\text { adapted to each set of } \\
\text { conditions and par- } \\
\text { ticipants }\end{array}$ & $\begin{array}{l}\text { Each consultation was tailored to the specific } \\
\text { needs and contexts of each country considering } \\
\text { language preferences, appropriate visual tools and } \\
\text { exercises. } \\
\text { Participants were invited to engage in roles and } \\
\text { discussions where they felt most comfortable; for }\end{array}$ \\
\hline
\end{tabular}




\begin{tabular}{|l|l|l|}
\hline & $\begin{array}{l}\text { example, by allowing the groups to appoint their } \\
\text { own representatives and allowing for space to re- } \\
\text { port back and provide feedback to previous discus- } \\
\text { sions, participants felt more empowered. }\end{array}$ \\
\hline $\begin{array}{l}\text { Development workers } \\
\text { facilitate the agenda } \\
\text { and priorities of local } \\
\text { stakeholders }\end{array}$ & $\begin{array}{l}\text { Outside experts were engaged to act as facilitators } \\
\text { to assist workshop stakeholders in issue identifica- } \\
\text { tion, and to draw out participant priorities (i.e. } \\
\text { mebate and analysis of } \\
\text { change leads to } \\
\text { agreed, sustainable } \\
\text { action }\end{array}$ \\
ing).
\end{tabular}

Tab.1: Integration of PLA Approaches into Consultation Methodologies

Source: Own Data 


\section{Country Mapping Exercises: Research Findings and Implications for Programme Design}

\subsection{Population, employment and education data}

The definition of "youth" was found to vary in each of the five countries, as did the availability and quality of demographic information. For the purposes of comparison, data on each country was drawn from the World Bank and US Census Bureau. Although the programme works with different age groups, the following data on youth aged between 15 and 24 (see Table 2) is used to provide comparable data on the status of youth in the target countries.

\begin{tabular}{|l|l|l|l|l|l|}
\multicolumn{2}{|c}{ Egypt } & \multicolumn{1}{c}{ Jordan } & Morocco & Tunisia & Yemen \\
\hline $\begin{array}{l}\text { Total population } \\
(2012)^{1}\end{array}$ & $83,688,164$ & $6,508,887$ & $32,309,239$ & $10,732,900$ & $24,771,809$ \\
\hline Sex ratio (2012) & 102.6 & 103.3 & 96.8 & 99.4 & 103.0 \\
\hline $\begin{array}{l}\text { Youth 15-19 } \\
(2012)^{1}\end{array}$ & $7,730,203$ & 690,479 & $2,965,295$ & 904,035 & $2,782,779$ \\
\hline $\begin{array}{l}\text { Youth 20-24 } \\
(2012)^{1}\end{array}$ & $7,530,430$ & 620,240 & $2,952,784$ & 930,073 & $2,449,933$ \\
\hline $\begin{array}{l}\text { Youth 15-24, \% } \\
\text { of total populati- } \\
\text { on (2012) }\end{array}$ & $18.2 \%$ & $20.1 \%$ & $18.3 \%$ & $17.1 \%$ & $21.1 \%$ \\
\hline $\begin{array}{l}\text { Unemployment } \\
\text { rate, general } \\
\text { population }\end{array}$ & $\begin{array}{l}9.4 \% \\
(2009)\end{array}$ & $\begin{array}{l}(2.9 \% \\
(2009)\end{array}$ & $\begin{array}{l}10.0 \% \\
(2009)\end{array}$ & $\begin{array}{l}14.2 \% \\
(2008)\end{array}$ & $\begin{array}{l}14.6 \% \\
(2009)\end{array}$ \\
\hline $\begin{array}{l}\text { Unemployment } \\
\text { rate, youth aged } \\
15-24^{2}\end{array}$ & $\begin{array}{l}24.8 \% \\
(2007)\end{array}$ & $27 \%$ \\
$(2009)$ & $\begin{array}{l}21.9 \% \\
(2009)\end{array}$ & $\begin{array}{l}30.7 \% \\
(2005)\end{array}$ & $\begin{array}{l}\text { (age } \\
\text { bracket not } \\
\text { defined })^{3}\end{array}$ \\
\hline
\end{tabular}




\begin{tabular}{|l|l|l|l|l|l|}
\hline $\begin{array}{l}\text { Youth literacy } \\
\text { rate (15-24) }\end{array}$ & $\begin{array}{l}85 \% \\
(2006)\end{array}$ & $\begin{array}{l}99 \% \\
(2007)\end{array}$ & $\begin{array}{l}79 \% \\
(2009)\end{array}$ & $\begin{array}{l}97 \% \\
(2008)\end{array}$ & $\begin{array}{l}84 \% \\
(2009)\end{array}$ \\
\hline $\begin{array}{l}\text { School enrolment } \\
\text { rate, tertiary } \\
(I S C E D \text { 5 and 6) }\end{array}$ & $\begin{array}{l}32 \% \\
(2010)\end{array}$ & $\begin{array}{l}38 \% \\
(2010)\end{array}$ & $\begin{array}{l}13 \% \\
(2009)\end{array}$ & $\begin{array}{l}34 \% \\
(2009)\end{array}$ & $\begin{array}{l}10 \% \\
(2007)\end{array}$ \\
\hline
\end{tabular}

Tab. 2: Selected Demographic Data for Project Countries

Sources: ${ }^{1}$ From US Census Bureau, ${ }^{2}$ From World Bank Data Catalog, World development Indicators, ${ }^{3}$ World Bank data unavailable, figure taken from UNDP Millennium Development Goals Yemen Report 2010.

With youth aged 15-24 comprising approximately $20 \%$ of the population in each of the countries, it is evident that a significant "youth bulge" exists in the region. Sex-disaggregated population pyramids paint an even more striking picture with the bulk of population in each country being under the age of 30 (see Figure 1). Some literature suggests that such youth bulges can lead to a number of societal challenges including social unrest and unemployment (Fuller 2004). This may well be the case in the Arab region; the data also indicates extremely high rates of youth unemployment, in some cases more than double the unemployment rates of the general population.

In addition, each of the mapping reports highlighted the challenges youth face in transitioning to adulthood (e.g. delays in marriage, labour market entry and departure from parental household). These findings indicate that the timelines along which young people do or do not reach these traditional markers of adulthood may be considered just as important as age brackets when considering definitions of youth. 

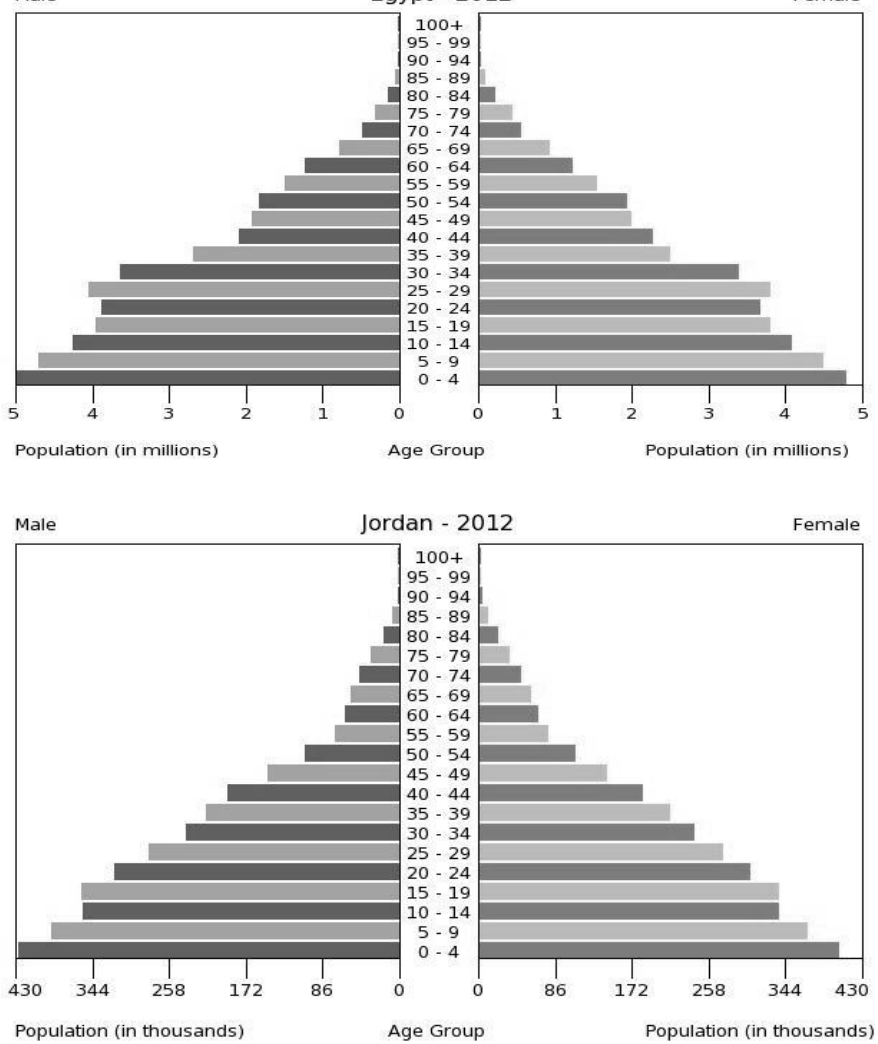

Male Female

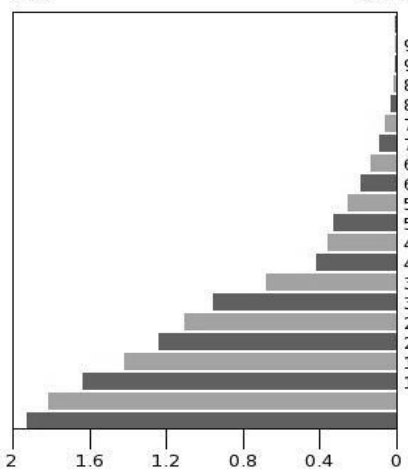
$\mid \begin{gathered}100+ \\ 95-99 \\ 90-94 \\ 85-89 \\ 80-84 \\ 75-79 \\ 70-74 \\ 65-69 \\ 60-64 \\ 55-59 \\ 50-54 \\ 45-49 \\ 40-44 \\ 35-39 \\ 30-34 \\ 25-29 \\ 20-24 \\ 15-19 \\ 10-14 \\ 5-9 \\ 0-4\end{gathered}$

12

Population (in millions)

Age Group

Population (in millions) 

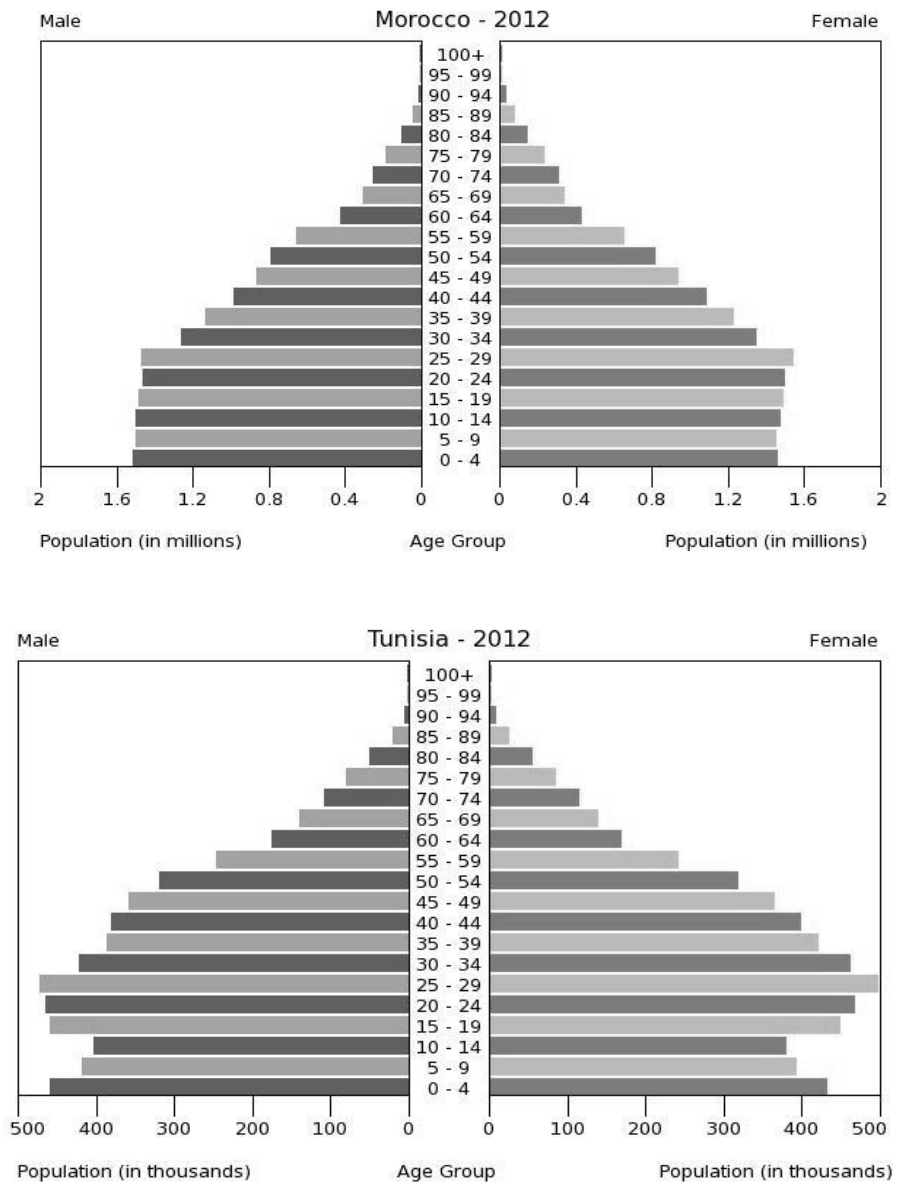

Fig. 1-5: Sex-disaggregated population pyramids

Source: United States Census Bureau

\subsection{Current policies and legislations related to youth}

A review of documents related to national youth policies found that Egypt, Jordan, Morocco and Yemen all have official youth strategies while Tunisia has specific legislation related to volunteerism. There also seems to be some 
evidence that government priorities and perceptions of youth issues have changed since the popular protest in the region. For example, both Morocco and Tunisia have changed youth policies as a direct reaction to political events: Morocco increased youth involvement via a July 2011 constitutional referendum while Tunisia dismantled the national 21/21 and 26/26 programme funds for youth and replaced them with new policies.

Also of note at the regional level is the proposed establishment of the Arab Youth Observatory, a think-tank dedicated to youth issues within the Arab countries. Announced at the $34^{\text {th }}$ meeting of Arab Ministers responsible for youth affairs, the development of this initiative indicates a stronger interest among governments in youth issues. It is anticipated that Morocco will chair the Observatory and manage its secretariat.

It is possible that these various governmental policies and regional frameworks could be used as a springboard for programme initiatives to encourage youth engagement. However, it will be important to ascertain which of these initiatives are genuinely backed by political will. Furthermore, newer initiatives are still being tested, while more long-standing initiatives have not necessarily achieved results, as evidenced by continued youth disenfranchisement in the different countries. Questions on whether to advocate for improvement to existing frameworks or to champion new models, and to what extent, will be considered in programme design.

\subsection{Government institutions involving youth}

In all five project countries, there exist multiple governmental institutions with responsibility for youth issues, with the lead agency for many of the countries being the Ministry of Youth and Sport or a Council of Youth. However, with education and employment being key issues expressed by youth in the region, it is also worth noting which ministries are not involved in youth issues. Tunisia and Yemen seem to be the only countries where the ministries involved with employment (i.e. Ministry of Social Affairs and Employment for Tunisia, Ministry of Social Affairs and Labour for Yemen) also have some explicit responsibility for youth, whereas Egypt and Tunisia include some responsibility for youth in their respective Ministries of Education. 


\subsection{Foremost challenges faced by youth}

Based on the mapping exercises, there are a number of challenges faced by youth in the region. Some of the broadest challenges include youth exclusion from political and civic processes, extremely high rates of unemployment and underemployment, as well as weak educational systems with inadequate linkages to labour market needs.

In addition, youth face new challenges as the meaning of adulthood and family formation have changed due to delays in traditional milestones such as leaving the family home, marriage and employment. Gender inequality inherent in some cultural traditions and norms may restrict the participation of young women in youth-focused activities, while poor intergenerational communication can potentially lead to conflict, particularly with concurrent shifts in cultural, social and religious norms. There are also issues around the lack of health information and health services, particularly related to sexual and reproductive health, sexual violence and drugs

Lastly, there are a number of barriers to accessing existing youth programmes, including negative perceptions of youth institutions by parents, a lack of media coverage on youth programmes and remote or inconvenient locations of youth centres.

\subsection{Youth visions for solutions}

A number of macro- and micro-level solutions to the aforementioned challenges are proposed by youth in the region. Most of these suggestions were derived from surveys and other documents focused on youth and their own perceptions of necessary change, although some refer to academic literature. Solutions include both those that involve youth directly, as well as suggestions on how other institutions such as civil society organizations, government, families and others can better facilitate social change.

- Educational reform: A number of targeted strategies to reform national educational systems are proposed, including curriculum review, improvements to the quality of education, exploration of alternative educational models. 
- Greater opportunity for youth involvement in civic and political processes: This includes promoting more opportunities for youth involvement in governance, offering new avenues for participation, leveraging existing online and offline social networks, and political reforms to combat corruption.

- Improved access to health information and services: Proposed solutions include monitoring of youth health and well-being, increased information on health, including on sensitive topics such as sexuality and violence, and better health service provision.

- Increased employment opportunities for youth: Suggested strategies include youth-focused employment creation, involvement of all stakeholders including government, civil society, private sector and the media, and the creation of concrete employment assistance services such as helpdesks.

Among these proposed solutions, there are a few notable differences between the countries. Overcoming and eliminating gender discrimination was only found to be mentioned explicitly in the Egypt review. In Morocco, the mapping report highlights the need to overcome youth reluctance towards civic engagement. The Tunisia mapping report also mentions the need for targeted financial and technical assistance from the European Union to help create employment and economic opportunities (e.g. reduce barriers to trade, offer exchange opportunities).

It is also noteworthy that despite the long list of challenges described in the previous section, the proposed solutions seem to focus on a few key areas, indicating that these are the most pressing issues being faced by youth. The issues of employment, exclusion and education came up repeatedly in both the mapping and consultation processes.

\subsection{Social media: A key tool for youth engagement}

Social media was found to be extremely popular among youth in the region. The most popular applications across all five countries seem to be Twitter and Facebook, although other applications such as LinkedIn, YouTube, blogs, websites, SMS/text messaging and MSN Messenger are also common. These tools have been successfully used to facilitate social interaction and civic engagement both online (e.g. for advocacy and information shar- 
ing) and offline (e.g. the use of cyber cafes as gathering spaces, the use of online tools to organize face-to-face gatherings and meetings). While the use of social media is increasing, there are still cost and access barriers for some segments of the population. Indeed, some of the statistics found on internet and Facebook penetration are lower than perhaps would be expected; for example, the Facebook rate in Yemen was only 1.37 percent in 2011 (ILO 2011) while the proportion of young people using the internet in Egypt was 7.5 percent (The Population Council 2011).

Most critically for the Arab Youth Volunteering for a Better Future programme, the mapping exercises found that social media was clearly seen as an effective agent for facilitating youth civic engagement in the region, consistent with the significant existing research on the role of social media in the Arab Spring movements (Allagui and Kuebler 2011, Chebib and Sohail 2011, Chokoshvili 2011, Howard and Hussain 2011, Stepanova 2011, Zhuo et al 2011). Findings from the Yemen mapping exercise highlight thoughts from a prominent activist about how social media played a role in the political uprisings, succinctly summarized as: breaking the fear and silence; organizing; spreading news; documenting human rights violations; global solidarity; and learning and knowledge sharing (Alwazir 2011).

With the prevalence of its use, social media will be a key tool for any youth volunteerism initiative. The question will be how to most effectively use it. Linking up with popular websites or harnessing popular bloggers as spokespeople may be effective methods. Integrating direct youth-to-youth communication will also be critical to ensure that social media messages have legitimacy. Nevertheless, given the statistics that indicate social media use is not universal or even widespread in some regions and sectors, it will also be important not to depend on social media as a "magic bullet" for communicating with youth.

In addition, while the mapping exercises primarily focused on how youth use media, it will also be imperative to look at how governments, civil society and the private sector can use social media to reach youth. Certainly government and civil society actors, both within and outside the Arab states region, have attempted to do so in recent years, albeit with mixed results. Looking to these examples may be useful in gleaning ideas and best practices for this programme. 


\subsection{Perceptions of volunteering}

The literature on Arab youth perceptions of volunteering is somewhat spare and provides differing viewpoints. Studies undertaken by the Euromed III youth programme have examined youth policies in the Mediterranean region and found widely varying angles in four of the five project countries. The concept of volunteerism was thought to not truly exist in Morocco (Floris 2009a), but was found to be both understood and recognized in Jordan with particular support from initiatives through the Royal Family (GorakSosnowksa 2009); volunteerism was viewed as "a path to launch their adult lives" and primarily seen through a religious lens in Egypt (Abdelhay 2009), while there was found to be confusion between recognized volunteers and unpaid workers in Tunisia (Floris 2009b). It seems that studies about volunteering in the region have not found youth views which reflect the perspective of volunteering as a legitimate means to develop useful skills, experiences and contacts for transitioning to the labour market. However, the later section of this paper will show that many youth reflected on skill development during the national consultations, indicating that this might be a newly developing perspective.

Generally, however, volunteering is perceived to be associated with two main ideas: religious faith and the concept of charity or "doing good". The Jordan mapping exercise found that a willingness to participate in community service for self-interest exists to some extent in the country, while the Tunisia mapping exercise found that volunteering is additionally sometimes perceived as an opportunity for socializing and combatting loneliness and routine.

The mapping exercises also explored the specific terminology used for volunteering. In Egypt, the term volunteering has historically been associated with voluntary military service or donations; in Morocco, too, the word was found to have military connotations, although this has shifted with the influence of international volunteerism. The Morocco mapping also indicates some overlap in meaning with the French term "bénévolat", which encompasses ancestral forms of solidarity and community practices. The Moroccan and Tunisian mappings provided extensive lists of Arabic words used for the concept of volunteering, whose English translations range from “in the way of Allah (God)” (في سبيل اللة) to "pass time" (يمي الوقت). This indicates the need for the clear use of terminology and translations with 
attention to local dialects and regional differences when developing initiatives to encourage volunteerism.

\section{Consultation Workshops: Research Findings and Implications for Programme Design}

\subsection{What it means to volunteer: definitions, perceptions and motiva- tions}

Participants generally felt it was difficult to find explicit definitions of what volunteering means in each of the five target countries. While the Tunisian national government has a formal definition and supporting legal framework for volunteering, the other four countries do not have an official definition of volunteering. This fact has likely contributed to some of the confusion and misperceptions of what voluntary action means.

Consultation participants across all countries felt that volunteering is an act of free will that can provide benefits for both the individual (by offering an opportunity for skills development as well as a sense of happiness and personal satisfaction) and for the community at large. These same reasons were also offered as motivating factors. Some differences were found where consultation participants in some countries noted negative perceptions of volunteering (e.g. additional work on top of personal and social duties, no compensation or financial gain).

Feedback from the consultation sessions on perceptions of volunteerism echoes some of the themes found in the mapping exercises and the existing literature, in that religious belief and "doing good" are considered to be the main drivers of volunteerism. In essence, volunteerism is seen as both a religious and civic duty, though changing political environments may affect what volunteering and civic engagement means.

Motivations for volunteering were very similar across all countries surveyed, and can be divided into four categories as suggested by the workshop facilitators: (1) achieving social cohesion; (2) employability; (3) active citizenship; and (4) personal development. There were many "soft/intangible" reasons listed (e.g. feeling good, social or religious benefit), as well as "hard/tangible" reasons, which were primarily related to economic and political benefit (e.g. increased employability, opportunity for involvement 
in politics). Egypt was the only country where the opportunity for women to engage in their community within the confines of cultural boundaries was specifically mentioned as a motivating factor, while the feedback from Morocco was the most explicit in situating volunteering within the context of traditional cultural norms and values.

Previous research on motivations for volunteering in the Arab states context was very scarce; of the two articles found during this review, one focuses on ethnic and religious motivations (Flanigan 2011) while the other explores economic and political motivations (Mercy Corps 2011). But related theoretical literature is consistent with the feedback from the consultations that the motivations for volunteer action are both important to understand and highly variable (Yeung 2004, Shye 2010). Voluntary action is undertaken by individuals who may have motivations that do not match the general trends. For example, while there seems to be a common theme among the five countries surveyed that voluntary action is aligned with religious faith, there will be people for whom this is not the case. Assuming otherwise in programme design may lead to strategies which alienate rather than encourage potential participants. Addressing this challenge may simply be a matter of targeting messages appropriately, or it may require alternate activities and strategies to reach different sub-populations with different motivations in each country.

In addition, the importance of involving citizens in voluntary action from a young age came up repeatedly during the consultations. This finding may provide strong rationale to link volunteerism with existing youth institutions (e.g. sports clubs, schools and universities). In particular, family members and religious institutions will be key actors in encouraging positive attitudes towards volunteering in young children. Initiatives to promote volunteering should not only target children and youth but also older people to create a trickle-down effect.

\subsection{Barriers to volunteer engagement}

Existing primary research on barriers to youth voluntary engagement has focused primarily on high-income regions such as North America and Europe, with less attention paid to middle- and low-income regions such as the Arab states region. The consultations revealed a wide array of factors in each of the project countries that represent barriers to voluntary engagement. These can be broken down into four categories: (1) economic, (2) cultural, 
(3) social and (4) infrastructural. It should be noted that these categories clearly have overlaps. In addition, a cross-cutting theme across all four of these categories is politics, along with a general sense of frustration with political systems and government.

Of note is the fact that even though the meaning and nature of youth volunteerism shifted radically during the Arab Spring movement, the longstanding barriers listed in this section have not necessarily changed since that time. But based on the feedback from the consultations what actually has changed is youth desire and empowerment to overcome these barriers and become more involved in social change.

\subsubsection{Economic barriers}

It is clear that unemployment and a lack of financial support for civil society organizations are the most pressing barriers to youth volunteerism. Many youth feel that they simply do not have the time to volunteer when they need to use their free hours to participate in or seek income-generating activities.

Voluntary participation is made even more difficult when organizations are not able to offer financial allowances to support volunteering, or when the connection between volunteerism and skills development for employability is not always clear. Participation may be particularly difficult in rural areas.

\subsubsection{Cultural barriers}

Cultural norms can impact the ability of marginalized groups to participate in civic engagement activities, including political forums. In particular, the exclusion of women and youth was highlighted as a significant cultural challenge in all five project countries. Yet it was also noted that the issue of gender can be a sensitive topic and therefore needs to be addressed with caution in order not to generate reverse impact and resistance to women's participation in voluntary activity.

The consultation feedback indicated that there was an absence of a "culture of volunteerism" in all five countries, which is further compounded by misconceptions of what volunteering actually is. The influence of tribal leaders or special interest groups on decision-making processes was also mentioned as a factor which can lead to the exclusion of other groups, including youth. 


\subsubsection{Social barriers}

The issue of a lack of a "culture of volunteering" came up again here, not within the context of traditional or ethnic cultural norms, but rather within the context of social norms. Certainly a lack of awareness and knowledge about volunteerism was found to be widespread. But worse, there were misconceptions and negative attitudes towards volunteering. The Jordan consultation was the most explicit on this, with consultation participants raising questions such as "Why do something for free?" and "Isn't it a waste of time?".

Youth exclusion from political and social processes was also cited as a challenge. Consultation participants stated that youth may feel as though they are "bad citizens" because they are not involved in decision-making processes at any level. Such negative feelings may in fact perpetuate a cycle of disengagement - a feeling of "why bother?" - rather than act as a motivator to involvement.

There was also a sense in some of the consultations that civil society organizations (CSOs) may not always be trustworthy or legitimate. In some cases, it was highlighted that nepotism and personal connections to CSOs may take precedence over skills and capability in volunteer selection processes. Some secondary barriers included the absence of role models for volunteering (Egypt and Morocco), and security issues which hinder physical movement, thus creating a barrier to engagement (Yemen).

\subsubsection{Infrastructural barriers}

The lack of social and legal frameworks to support voluntary action was felt to be a significant barrier to participation, particularly for youth. Consultation of participants from all countries cited a general absence of official government interest or involvement in policies, legislation and strategies related to youth and the voluntary sector. The Tunisia and Yemen consultations both highlighted how the lack of legal structures may lead to volunteers being exploited.

In addition, the financial and structural weaknesses of CSOs and the civil society sector were mentioned, especially in regards to training and preparation for volunteers. There are few, if any, networks which bring together volunteers, CSOs and other civil society stakeholders. As a consequence, 
there are few avenues for strengthening collaboration within the sector, let alone for sharing information about volunteer opportunities or skills training for volunteer managers.

\section{Proposals For Programme Design}

The consultation sessions yielded a rich variety of tangible proposals and possible next steps to encourage youth voluntary action in each of the countries. These proposals can be divided into the following four categories: (1) fostering a "culture of volunteerism"; (2) developing supportive infrastructure for volunteering; to (3) developing capacity support volunteerism; (4) and creating opportunities for inclusion.

\subsection{Fostering a "culture of volunteerism"}

The importance of developing positive attitudes towards volunteerism was found to be a common theme. A number of tools were suggested to advocate for volunteerism, such as the use of the media (all), celebrations of International Volunteer Day (Jordan, Morocco and Yemen), interactive theatre (Yemen) and workshops, conferences or field trips (Egypt, Morocco, Tunisia, and Yemen). Social media is also a tool that would be highly useful here. Strategies to better motivate and retain volunteers are also suggested, including an increased focus on rewards and recognition for individual volunteers (Egypt, Jordan and Morocco).

Engaging diverse stakeholders in fostering a culture of volunteerism is also of critical importance. Involving schools, post-secondary institutions, families, religious institutions and private companies in communication initiatives is suggested. This includes engaging individuals from these sectors, as well as utilizing physical spaces. For example, the recruitment of religious leaders, government figures and celebrities to act as role models or volunteer champions is suggested as a strategy, but the Morocco consultations also suggest the creation and display of paintings with information on voluntary activities inside educational institutions and even within private homes.

In particular, aligning values of volunteerism with religious values and practice is highlighted as a key approach. Suggested strategies include harnessing the religious discourse to promote volunteerism (Egypt), asking religious leaders to advocate for volunteerism through religious centres or 
events such as Friday night mosque prayers (Jordan) and developing awareness campaigns targeted to religious leaders (Yemen).

\subsection{Developing supportive infrastructures for volunteering}

In all the five country consultations there was a strong emphasis on the need to strengthen the infrastructure required to support volunteerism. Recommendations included creating volunteering centres or units and establishing volunteering databases to facilitate volunteer recruitment and management.

In particular, feedback from all country consultations pointed to the importance of governments upgrading and/or developing clear legislation, policies and strategies on youth volunteerism. This includes initiatives ranging from national strategies on volunteering (Egypt and Morocco) to legal frameworks (Egypt, Jordan, Tunisia, Yemen), as well as the creation of opportunities for new youth groups and specific roles to support government initiatives on youth and volunteering (all countries). Direct involvement of youth in the development of these strategies will be critical.

\subsection{Developing capacity to support volunteerism}

Across all the consultations, there was an emphasis on the need to develop stronger civil societies. This includes increased general financing to either support CSOs directly or to help create incentives and remove financial barriers for volunteering, as well as capacity development for individual organizations. Increased financial and political support of the sector by the government is also recommended.

In particular, there are a number of proposals targeted at strengthening the capacity of civil society and private organizations to undertake volunteer engagement. This includes the publication of best practices and knowledge guides on volunteerism (Egypt), developing training sessions and manuals on volunteer management (Jordan) and developing training opportunities on related topics such as advocacy, fundraising and partnerships (Morocco) as well as codes of conduct (Tunisia, Yemen). Such training sessions could also be offered as skills-building opportunities for youth, thereby better equipping them to act as volunteers. There are also a number of creative strategies suggested for the private sector, such as advocating for private companies to 
encourage volunteer work through tax benefits or by encouraging four hours of volunteer work for employees per month (Jordan).

Lastly, there are suggestions which encourage greater knowledge and information sharing. Many of the consultations called for the creation of offline and online networks or directories for information sharing and support, while consultation participants in Egypt and Jordan also called for more research on volunteerism.

\subsection{Creating opportunities for youth inclusion}

Youth exclusion was mentioned throughout the mapping and the consultations, and it is evident that new methods and strategies are needed to address this challenge. To overcome social and civic exclusion, suggestions included developing new youth bodies, such as elected youth councils (Egypt), creating opportunities for youth to take on leadership roles in existing youthfocused organizations (Egypt), developing clubs specialized in volunteering in youth centres and cultural centres (Morocco), engaging youth in think tanks, focus groups, workshops and surveys (Tunisia) and creating opportunities for mentorship (Jordan).

There were also a number of suggested strategies on how volunteerism can help address economic exclusion. In some ways, this may simply be a matter of education and awareness-raising on how volunteer engagement can increase employability through skills development, work experience or making new contacts. However, there were also proposals to reduce financial challenges that may be associated with volunteering. For example, consultation participants in Jordan suggested providing compensation such as vouchers and certificates as part of recognition programmes, organizing carpooling incentives for volunteers or offering public transport benefits for volunteers. The implication here is that while volunteers may engage in activity without financial compensation, it is not cost-free to engage volunteers. Adequate funding support is required.

Strengthening linkages between volunteerism and education systems was often a proposed way forward. Possible strategies include developing educational curriculum that is market driven and linked to the professional world (Egypt), integrating community service in educational curricula (Jordan), creating job opportunities in education institutions for volunteerism facilita- 
tors and promoters (Morocco), creating scholarships or reducing fees for students with volunteering experiences when they apply to study at universities (Morocco), and including the topic of volunteerism in educational programmes (Tunisia, Yemen).

Specific initiatives were also suggested to encourage gender equity and ensure the inclusion of young women in voluntary action. The Yemen consultations mention a number of strategies to do so within the country's social and cultural boundaries, including gender-segregated activities and meetings in conservative regions, avoiding late-night work for women and providing financial support to allow chaperones to travel with women as required. Other countries also advocated for gender-sensitive approaches (Tunisia) or making special efforts to ensure that volunteering programmes are inclusive of or provide targeted opportunities for marginalized groups, including women (Egypt, Jordan).

\section{Conclusion and Outlook}

In the wake of the recent political uprisings, the Arab States region is at a critical juncture in developing new perspectives and approaches to youth volunteerism. While forms of voluntary engagement certainly existed well before 2010, the findings from the mapping exercises and national consultations indicate a cautious hopefulness about what may be possible in the future. However, sustaining this momentum may be difficult in the longterm, especially if youth do not feel their situation is improving.

As the Arab Youth Volunteering for a Better Future programme moves forward, findings and perspectives from the preliminary participatory research will be incorporated into programme design and implementation. It is clear from the consultations that voluntary engagement is seen as a religious and civic duty. But it is not always clear that youth understand the reciprocal nature of volunteering and that it can provide them with tangible benefits beyond "feeling good", particularly around skills development and increasing their employability. Appealing to youth's self-interests and highlighting how volunteering can in fact help them as well as their community could be an important message for this programme.

The feelings of exclusion cited by youth also point to the fact that broader change will not be possible without the participation and support of all 
stakeholders. It is not simply a matter of creating opportunities and spaces for youth, but also ensuring that youth feel their voices are heard and respected. Opportunities for political and civic engagement will ensure this. While the mapping and consultation exercises highlight the need for involvement of national government, there is also a need for engagement at municipal and provincial level which may present more local opportunities for voluntary participation at the local level, particularly outside of urban centres. Volunteering initiatives will also need to be sensitive to the specific political contexts of each country and to consider that volunteerism does not always have to mean activism, even if that is what it has meant in recent times.

\section{Bibliography}

Abdelhay, Ahmed Tohami (2009): Euromed Youth III Programme: Studies on Youth Policies in the Mediterranean Partner Countries - Egypt, European Union, MarlyleRoi, France.

Ali, Amira (2012): Volunteering for development in Egypt: examining the benefits of student volunteering on skills development and employability, American University of Cairo, Cairo.

Allagui, Ilhem and Kuebler, Johanne (2011): The Arab Spring and the Role of ICTs, Editorial Introduction, in: International Journal of Communication, no.5/2011, http://ijoc.org/ojs/ index.php/ijoc/article/viewFile/1392/616 (accessed on November 19, 2012)

Al-Momani, Mohammad (2011): The Arab Youth Quake: Implications on Democratization and Stability, in: Middle East Law and Governance, vol. 3, no. 1-2, p. 159-170(12).

Alwazir, Atiaf (2011): Hopes and Fears: London Conference on Cyberspace,Blog posting, http://womanfromyemen.blogspot.ca/2011/11/hopes-fears-london-conference-on.html, (accessed on November 20, 2012)

Arab Network for NGOs (2010): $10^{\text {th }}$ Annual Report of Arab NGOs: State of Voluntarism in the Arab Region, Cairo, Egypt.

Bradley, Dan and Helen Schneider (2004): Participatory Approaches: A Facilitator's Guide, VSO, London.

Chebib, Nadine Kassem, and Rabia Minatullah Sohail (2011): The reasons social media contributed to the 2011 Egyptian Revolution, in: International Journal of Business Research and Management (IJBRM), vol. 2, no. 3, pp. 139-162.

Chokoshvili, Davit (2011): The Role of the Internet in Democratic Transition: Case Study of the Arab Spring, Dissertation, Central European University, Budapest, Hungary.

Flanigan, Shawn Teresa (2011): Religious and ethnic motivations for serving others in the Arab World: Evidence from Lebanon, in Takaful: The First Annual Conference on Arab Philanthropy and Civic Engagement - Selected Research, John D. Gerhart Center for Philanthropy and Civic Engagement, Cairo, Egypt.

Floris, Sylvie (2009a): Euromed Youth III Programme: Studies on Youth Policies in the Mediterranean Partner Countries - Morocco, European Union, MarlyleRoi, France.

Floris, Sylvie (2009b): Euromed Youth III Programme: Studies on Youth Policies in the Mediterranean Partner Countries - Tunisia, European Union, MarlyleRoi, France.

Fuller, Graham (2004): The youth crisis in Middle Eastern society, Brief Paper, Clinton Township: Institute of Social Policy and Understanding. 
Gorak-Sosnowska, Katarzyna (2009): Euromed Youth III Programme: Studies on Youth Policies in the Mediterranean Partner Countries - Jordan, European Union, MarlyleRoi, France.

Halaseh, Rama (2012): Civil Society, Youth and the Arab Spring, in: Change and Opportunities in the Emerging Mediterranean, ed. by Stephen Calleya and Monika Wohlfeld, Mediterranean Academy of Diplomatic Studies, Malta, p. 254-273.

Hoffman, Michael and Jamal, Amaney (2012): The Youth and the Arab Spring: Cohort Differences and Similarities, in: Middle East Law and Governance, vol. 4, no. 1, pp. 168-188(21).

Howard, Philip N. and Muzammil M. Hussain (2011): The role of digital media, in: Journal of Democracy, vol. 22, no. 3, pp. 35-48.

Ibrahim, Barbara Lethem (2005): Strengthening Philanthropy and Civic Engagement in the Arab World: A Mission for the John D. Gerhart Center, Symposium Paper, American University in Cairo, Cairo.

International Institute for Environment and Development (IIED) (2011): Young Citizens: Youth and Participatory Governance in Africa - Participatory Learning and Action, Issue 64, IIED, London, UK.

International Labour Office Department of Statistics (2011): Data drawn from database at http://laborsta.ilo.org/, (accessed on November 19, 2012)

Issam Fares Institute for Public Policy and International Affairs (2011): A Generation on the Move: Insights into the Conditions, Aspirations and Activism of Arab Youth, American University of Beirut, Beirut.

Kandil, Amani (2004): Civic service in the Arab region, in: Nonprofit and voluntary sector quarterly, vol 33, no. 4 suppl, pp. 39S-50S.

Kandil, Amani (2010): A critical review of the literature about the Arab Civil Society, The Indicators of Arab Civil Society Organizations' Effectiveness, The Arab Network for NonGovernmental Organizations, Cairo.

La Cava, Gloria (2010): Investing in Youth in the MENA Region: Lessons Learned and the Way Forward, World Bank, Washington, DC.

Mercy Corps (2012): Civic Engagement of Youth in Middle East and North Africa: An Analysis of Key Drivers and Outcomes, Portland.

Population Council, The (2011): Survey of Young People in Egypt, Final Report, Cairo, Egypt.

Rishmawi, Mervat and Tim Morris (2007): Overview of Civil Society in the Arab World, INTRAC, Oxford, UK.

Salih, MA Mohamed (2004): The promise and peril of Islamic voluntarism, in: Islamism and its Enemies in the Horn of Africa, ed. by Alex de Waal, Indiana University Press, Bloomington, pp. 146-181.

Sedky, Razma Hussein (2011): Youth and Voluntary Work: Taking the Lead to a Brighter Future, Thesis to America University, Cairo.

Shtewi, Moussa et al. (2000): Volunteerism and Volunteers in the Arab World, Case Studies (in Arabic and English), The Arab Network for NGOs, Cairo.

Stepanova, Ekaterina (2011): The Role of Information Communication Technologies in the "Arab Spring”, in: Implications beyond the Region, George Washington University, PONARS Eurasia Policy Memo no. 159, Washington, DC.

Shye, Samuel (2010): The Motivation to Volunteer: A Systemic Quality of Life Theory, in: Social Indicators Research, vol. 98, no. 2, pp. 183-200.

Talcott, Fiona (2011): Broadening Civic Space Through Voluntary Action: Lessons from 2011, CIVICUS and UNV, Johannesburg, South Africa.

United Nations Educational, Scientific and Cultural Organization (UNESCO) (2011): Arab Youth: Civic Engagement and Economic Participation, UNESCO Regional Bureau for Education in the Arab States, Beirut, Lebanon. 
Abraham \& Al-Eryani, UNV: Youth Volunteerism in the Arab World

United Nations Development Programme (UNDP) (2009): Arab Human Development Report 2009: Challenges to Human Security in the Arab Countries, New York.

United Nations Volunteers (UNV) (2011): State of the World's Volunteerism Report: Universal Values for Global Well-Being, Bonn.

United Nations Volunteers (UNV) (2012): UNV and Arab Federation of Voluntary Activities sign an historic Memorandum of Understanding, http://www.unv.org/en/what-we-do/thematicareas/peace-conflict-resolution/doc/unv-and-arab-federation.html, (accessed on November 19, 2012)

Underwood, Carol, and Bushra Jabre (2010): Reflections on Civic Participation and Emerging Leadership in the Arab World, paper prepared for "Appreciating and Advancing Leadership for Public Wellbeing - A workshop Sponsored by NYU Abu Dhabi Institute".

Yeung, Anne Birgitta (2004): The Octagon Model of Volunteer Motivation Results of a Phenomenological Analysis, in: Voluntas, vol 15, no. 1, pp. 21-46.

Zhuo, Xiaolin, Barry Wellman and Justine Yu (2011): Egypt: The First Internet Revolt? , in Peace Magazine, July-Sept 2011, p. 6., Toronto. 


\section{Abstract}

Lesley Abraham und Waheeb Al-Eryani

United Nations Volunteers: Hindernisse und Chancen für freiwilliges Engagement von Jugendlichen in der arabischen Welt

Die arabische Region hat in den vergangenen Jahren einen außergewöhnlichen politischen, sozialen und wirtschaftlichen Umbruch erlebt. Dieser hat auch ein Schlaglicht auf die Armut, Arbeitslosigkeit und Ausgrenzung von Jugendlichen in der Region geworfen. Als Antwort auf diese Herausforderungen unterstützt United Nations Volunteers (UNV) das Programm „Arab Youth Volunteering for a Better Future“. Es hat zum Ziel, die Energie der Jugend durch Freiwilligenarbeit zu nutzen, um so die Inklusion und Teilhabe von Jugendlichen an der sozioökonomischen Entwicklung zu verbessern. Dabei kam ein partizipativer Ansatz aus Lernen und Handeln zum Einsatz, mit dem das Programm eine Reihe von Mapping- und Konsultations-Aktionen in fünf Pilot-Ländern durchführte (Ägypten, Jordanien, Marokko, Tunesien und Jemen). Dabei wurden Informationen erhoben zu Wahrnehmungen, Hindernissen und Chancen von Freiwilligenarbeit aus Sicht von Jugendlichen und anderen Stakeholdern. Der vorliegende Beitrag beschreibt sowohl den Prozess als auch die Erkenntnisse die aus den Aktivitäten gewonnen wurden. Zudem legt er dar, wie diese Erkenntnisse in die nächsten Schritte des ProgrammDesigns einfließen werden. Die Hindernisse für Freiwilligenarbeit können in vier Kategorien eingeteilt werden: Ökonomische, kulturelle, soziale und infrastrukturelle. Die vorgeschlagenen Lösungen beinhalten die Förderung einer Kultur der Freiwilligenarbeit, die Entwicklung einer unterstützenden Infrastruktur für ehrenamtliches Engagement, die Entwicklung nationaler Kompetenzen, um Freiwilligenarbeit zu unterstützen und die Schaffung von Möglichkeiten zur Inklusion.

Keywords: Nationale Konsultationen, Jugend-Freiwilligenarbeit, Arab Youth Volunteering, „Participatory Learning and Action“-Ansatz, Hindernisse für Freiwillige, United Nations Volunteers, Auffassungen von Freiwilligenarbeit in der arabischen Welt. 